\title{
Water circulation in the moraine ponds of northern Poland
}

\author{
Włodzimierz Golus • Elżbieta Bajkiewicz-Grabowska
}

Received: 13 November 2015/Revised: 4 April 2016/Accepted: 14 May 2016/Published online: 8 June 2016

(C) The Author(s) 2016. This article is published with open access at Springerlink.com

\begin{abstract}
The landscape of northern Poland is characterised by a very large number of ponds. Traditionally it has been assumed that their hydrology is determined by precipitation and evaporation, and that they are isolated from the adjacent river network. Recent studies, however, have shown that ponds contribute to river runoff for at least part of the year. Their existence is therefore additionally based on fluvial and underground water sources. In order to establish the principles of water circulation in typical ponds, we selected 14 ponds with seasonally intermittent streams. We measured water levels in these ponds and flows in the river segments that connect them. We also determined subsurface exchange fluxes from the water balance equation. Our results demonstrated that the hydrological functions of the ponds varied throughout the year and depended on the level of water storage in the pond's catchment. When the level of retention in the pond's catchment is low, the pond becomes a water body without surface outflow and a drainage base for groundwater. As the level of retention in the catchment rises, ponds develop surface outflows and reconnect
\end{abstract}

Guest editors: Mary Kelly-Quinn, Jeremy Biggs \& Stefanie von Fumetti / The Importance of Small Water Bodies: Insights from Research

W. Golus $(\bowtie) \cdot$ E. Bajkiewicz-Grabowska

Department of Lake Hydrology, Institute of Geography, University of Gdańsk, ul. Bażyńskiego 4, 80-952 Gdańsk, Poland

e-mail: geowg@ug.edu.pl with the river network. At this point, their main function becomes retention of water originating from subsurface and surface inflows. Any surplus water may be fed to underground or surface waters.

Keywords Ponds · Water circulation - Endorheic areas $\cdot$ Post-glacial landscape

\section{Introduction}

Post-glacial areas, which were formed during continental glacier recession nearly 10,000 years ago, extend from the northeastern part of Germany through the northern part of Poland to the Baltic countries, Belarus, and Russia. These geologically young areas contain multiple endorheic depressions that are relics of ice sheets and part of large areas that are permanently or seasonally devoid of surface outflow. The water network in these areas is quite characteristic. It is typified by a large number of water bodies of various sizes filling the beds of the numerous hollow landforms, with some of these water bodies being seasonally interconnected by short streams to form a single coherent drainage system. Ponds (kettle holes filled with water) are particularly numerous on undulating or hummocky moraine plateaus composed of poorly permeable clays. Ponds are typical elements of the agricultural landscape of northern Poland and are found in the majority of shallow depressions in the landscape. Most of the ponds found on the moraine 
plateaus of northern Poland and northeastern Germany are not connected with the river network (Kalettka et al., 2001; Gerke et al., 2010). They are therefore susceptible to changes of the levels of water storage in their respective catchments (wet-dry cycles) (Bajkiewicz-Grabowska \& Golus, 2009; Lischeid \& Kalettka, 2012).

Being located in endorheic catchments, these ponds are a trap for pollutants and sediments, which contributes to a rapid eutrophication of their waters (Noges et al., 2003; Davies, 2008; Lischeid \& Kalettka, 2012; Waldon, 2012). The morphometric features of the ponds (namely the small surface area and the very low depth) create specific ecological conditions for these aquatic ecosystems (Williams et al., 1999; Oertli et al., 2005; Davis et al., 2008; Oertli et al., 2009). The number of water bodies of less than 1 ha in area on the Polish Lowland has been estimated at several hundreds of thousands (Choiński, 1999). The number of ponds of less than 5 ha in area in Gdansk Pomerania (a part of the Polish Lowland) has been estimated at nearly 32,000 (Golus, 2014). Their density on moraine plateaus may be up to 80 per $1 \mathrm{~km}^{2}$.

The omnipresence of ponds and their important environmental roles (Biggs et al., 2005; De Meester et al., 2005) stand in stark contrast to the deficiency of research papers published so far by Polish authors. In Poland and in other countries, ponds are often considered synonymous with shallow lakes or wetlands (Wetzel, 2001), or even with endorheic depressions of land (Drwal, 1990; Kalettka et al., 2001; Pieńkowski, 2006; Major, 2009), and have only recently begun to attract the interest of biologists, geomorphologists, hydrologists and agricultural scientists. The current body of knowledge in this area is still very limited. The presence of ponds situated in endorheic depressions is thought to be determined by the atmospheric exchange of water, i.e. by precipitation and evaporation (Drwal, 1982; Drwal \& Lange, 1985; Drwal, 1990; Lehsten et al., 2011). The amount of water stored in the pond depends on the flux of the atmospheric exchange of water. It is therefore commonly believed, especially by authorities responsible for agriculture, that the fundamental hydrological function of ponds in endorheic areas is to collect and store water gained from precipitation and lost by evaporation (Fiedler, 2002; Lehsten et al., 2011). Most hydrologists are aware of the fact that ponds have contact with groundwater (Lehsten et al., 2011), but still insufficient information is available on the role of ponds in the water cycle. Ponds have traditionally been considered unimportant for the functioning of river networks, and have so far been regarded as typical of and exclusive to endorheic areas (Drwal \& Lange, 1985; Drwal, 1990).

Despite their considerable ecological significance (Boix et al., 2012), ponds are not protected by Polish law. The common belief is that these water bodies are devoid of surface outflow and have no connection with groundwater, which allows private owners to manage them any way they like, for instance, to convert them to fish ponds, to drain and fill them in, or to use them for disposing of sewage and waste (Marszelewski \& Podgórski, 2004; Pieńkowski, 2004).

Kalettka \& Rudat (2006) indicated that some of the moraine ponds in the northeastern part of Germany tended to overflow during high-water levels. Recent studies conducted in Gdansk Pomerania have shown that nearly $20 \%$ of the ponds located in endorheic depressions contribute to river runoff for at least a part of the year (Bajkiewicz-Grabowska \& Golus, 2009; Golus, 2014), which implies that these water bodies not only store water from precipitation and lose it by evaporation but also have additional, hydrological functions. The results of these studies suggest that these ponds are a key factor in initiating runoff from postglacial areas, and that some of them supply aquifers, which is why we called them "hydrogeological gates". It may therefore be concluded that they play an essential role in water circulation in the post-glacial landscape and that their presence there affects the functioning of larger objects, such as lakes and rivers. Downing (2010) has shown that these small bodies of water play an important role in the circulation of water and sediment not only in the regional but also global scale. Results of the studies of small water bodies on the American prairies (Woo \& Rowsell, 1993; Winter \& Rosenberry, 1995; Ferone \& Devito, 2004; Skalbeck et al., 2009) have suggested that they are connected with groundwater reservoirs. This has also been demonstrated in a number of studies of moraine ponds in Mecklenburg, Germany (Lehsten, 2011).

Investigating the hydrological cycle in ponds is important not only for reasons associated with water management in post-glacial areas, but also because it is the key to gaining an understanding of how these aquatic ecosystems function. Duration of water retention and routes of water exchange in the pond are 
factors that determine the stability of chemical composition of its water (Lischeid \& Kalettka, 2012) and the biodiversity (in terms of species and their numbers) of its aquatic ecosystem (Lehsten, 2011).

In light of the difference between the opinion of researchers and the deeply rooted common belief, we tried to answer the following questions in our study: Are the moraine plateau ponds of northern Poland connected to ground water reservoirs and river network? Are these ponds a significant element of moraine plateaus? Do we know enough to properly understand the function of ponds? Is this knowledge important for their future existence? Can water balance of interconnected ponds be calculated without the use of expensive specialist equipment? Is the water balance equation (a fundamental equation in hydrology) enough to fill the gaps in the knowledge of water circulation in ponds?

\section{Water balance}

A good understanding of water circulation in the environment is paramount to grasping the interrelations between the Earth and the atmosphere. One of the methods of illustrating the circulation of water is by the water balance equation (also referred to as 'water budget equation'). As Davie aptly points out (2008), the water balance equation is probably the closest that hydrology comes to having a fundamental theory underlying it as a science, and hence almost all hydrological study is based around it. It is assumed that the system is closed and that there is no loss or gain of either mass, as water, or energy from that system (Davie, 2008). The simplest water balance equation takes the following form:

$P \pm E \pm \Delta S \pm Q=0$,

where $P$ is the precipitation, $E$ is the evaporation, $\Delta S$ is the change in storage and $Q$ is the runoff.

The \pm sign signifies that each of the terms of the equation may either signify gain or loss, depending on the adopted point of reference, e.g. evaporation will be gain if the atmosphere is the point of reference and loss if the pond is the point of reference.

While in cases of rivers and river catchments the term runoff is the correct one, in cases of reservoirtype bodies of water (e.g. lakes and ponds, as opposed to streams and rivers), it is more appropriate to use term water flow instead. The water balance equation for water reservoirs in general, and for ponds in particular, will therefore take the following form:

$P-E+\Delta \mathrm{WF}-\Delta S=0$,

where WF is net water flow [where WF may either be water inflow $(W I)$ or water outflow $(W O)]$. For the sake of further discussion, we assume the pond to be the point of reference ( $P$ will therefore always be positive, $E$ negative, $W I$ positive and $W O$ negative). $\Delta S$ can be an income or outcome for a pond. The equation may be expanded as follows:

$P-E+(\mathrm{WI}-\mathrm{WO})-\Delta S=0$

As WF is composed of streamwater and groundwater, Eq. 3 may therefore be further expanded as follows:

$P-E+\Delta \mathrm{SWF}+\Delta \mathrm{GWF}-\Delta S=0$,

where SWF is streamwater flow and GWF is groundwater flow.

As we expand $\Delta \mathrm{SWF}$ and $\Delta \mathrm{GWF}$ to (SWI $-\mathrm{SWO})$ and (GWI - GWO), respectively, the water balance equation takes the following final form:

$$
\begin{aligned}
& (P-E)+(\mathrm{SWI}-\mathrm{SWO})+(\mathrm{GWI}-\mathrm{GWO})-\Delta S \\
& \quad=0,
\end{aligned}
$$

where SWI is streamwater inflow, SWO is streamwater outflow, GWI is groundwater inflow and GWO is groundwater outflow.

For the sake of simplicity, all the waters involved in the underground part of water circulation and also subsurface flow will be referred to as 'groundwater'.

As has already been pointed out, ponds may serve various hydrological functions. Ponds are most commonly assumed to have no connection to the river network and their connection with groundwater is affected by the precipitation surplus (Lehsten et al., 2011) (Fig. 1). Their water balance is also believed to be determined mainly by $P$ and $E$. Such ponds are rarely seen on the moraine plateaus of northern Poland.

In conclusion, the water balance equation for this pond type will be as follows:

$(P-E)-\Delta S=0$,

where $P$ is the precipitation, $E$ is the evaporation and $\Delta S$ is the change in storage. 


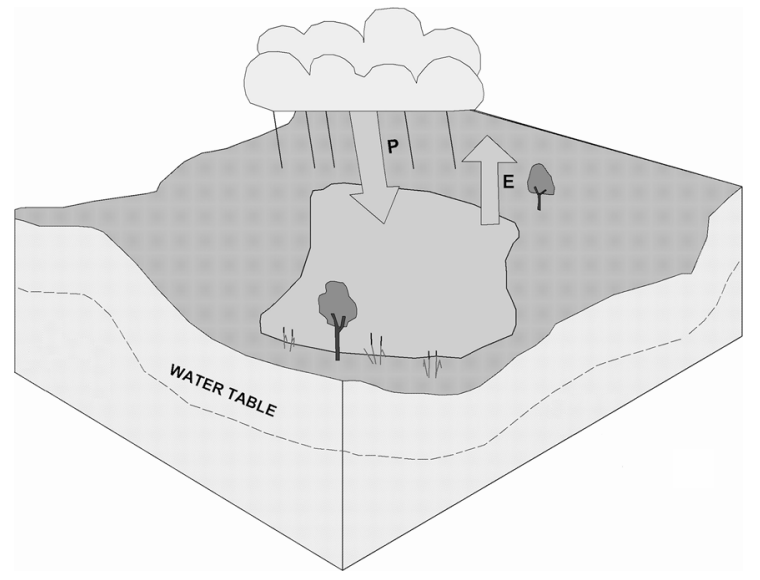

Fig. 1 A diagram of water circulation in a pond. Abbreviations $P$ precipitation, $E$ evaporation

As demonstrated in a field study (BajkiewiczGrabowska \& Golus, 2009), the specific features of water circulation in post-glacial areas render ponds that remain unconnected to the river network for most of the year (Fig. 2) susceptible to being connected to the river network for certain periods of the year. The water level in these ponds becomes high enough for the water to flow over the threshold of the depression in which the pond is situated. As a result, the ponds start to initiate stream flow (Fig. 3). Such ponds are typical of the moraine plateaus of northern Poland. The water balance equation for such ponds takes the form of Eq. 5.

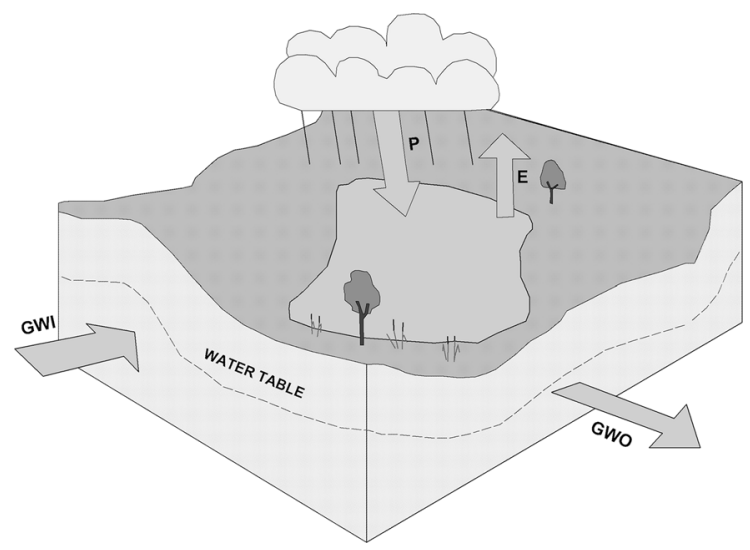

Fig. 2 A diagram of water circulation in a pond during the dry phase. Abbreviations $P$ precipitation, $E$ evaporation, $S W F$ streamwater flow, GWI groundwater flow, GWO groundwater outflow

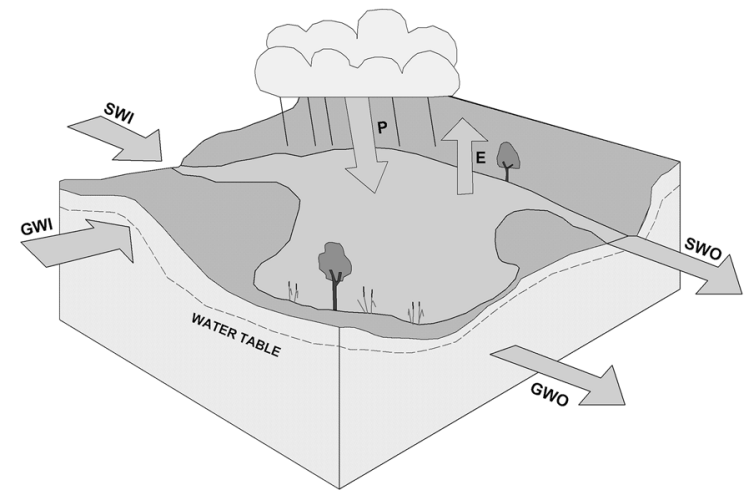

Fig. 3 A diagram of water circulation in a pond during the wet phase. Abbreviations $P$ precipitation, $E$ evaporation, $S W F$ streamwater flow, $G W F$ groundwater flow

\section{Materials and methods}

This paper defines hydrological functions of ponds situated in endorheic depressions based on documented by on-site measurements of the water circulation in these ponds. The study was conducted in a region of northern Poland called Wysoczyzna Brodnicka. It is an area typified by an undulating moraine landscape in which extensive agricultural areas predominate interspersed with forest areas. The research area includes an uncontrolled catchment of a periodic stream called Sznurówka, of $1.45 \mathrm{~km}^{2}$ in area (Fig. 4). Within its borders, the study included 14 permanent moraine ponds with an area ranging from 272 to $6177 \mathrm{~m}^{2}$ (Table 1). All the topographic data were obtained from 1:10,000 topographic maps. The database was created using ArcGIS. For each pond, we also measured the maximum depth in winter 2009. Because the ponds were small and shallow, there was no relationship between their depth and area. We assumed that other components of the environment, such as temperature, water mixing, plant overgrowth and water management, are less important.

Water balance of the ponds was calculated for the year 2009. A month was adopted as the basic balance period. The balance components were expressed in millimetres of the water layer.

Fluxes of water exchange between the pond and the atmosphere and between the pond and the surface catchment were estimated from the data obtained during on-site measurements: 


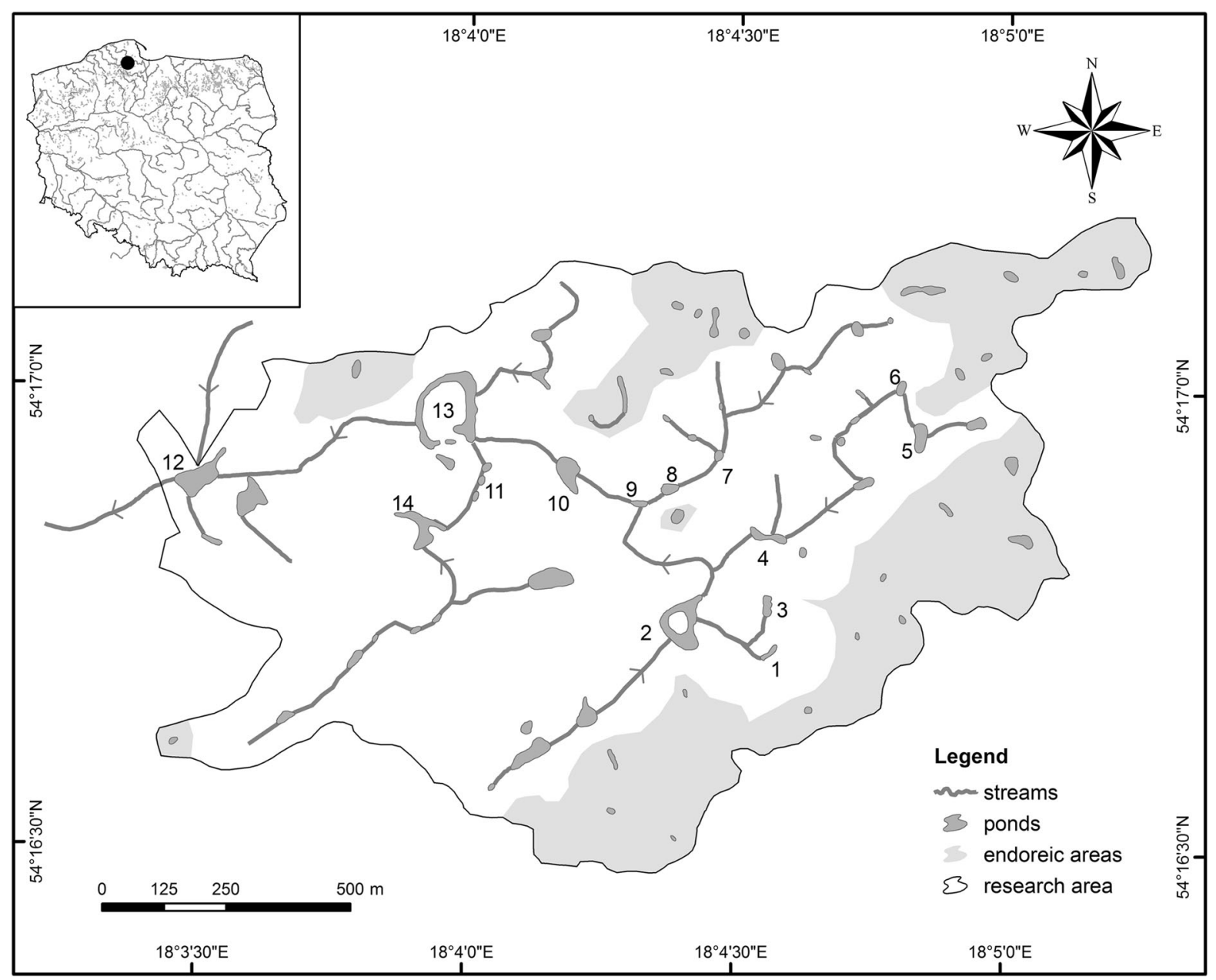

Fig. 4 The study area

1. Monthly $P$ [i.e. precipitation] sums were determined from the meteorological data recorded at the University of Gdańsk Lake Hydrology Station in Borucino, situated $6 \mathrm{~km}$ from the study area, so we assumed that the difference in precipitation between these to points was insignificant.

2. Monthly $E$ [i.e. evaporation] sums were calculated from the Ivanov formula, a formula widely used for northern Poland:

$E_{\mathrm{w}}=0.0018(25+t)^{2} \times(100-f)$,

where $E_{\mathrm{w}}$ is monthly evaporation $(\mathrm{mm}), t$ is monthly mean temperature $\left({ }^{\circ} \mathrm{C}\right)$ and $f$ is monthly mean relative humidity $(\%)$.

3. Net flow for each pond was estimated from the measurements of flows at the inlet and outlet of the pond performed on-site (Fig. 4) using a current meter (Valeport 801).

4. $\Delta S$ was determined by measuring changes in the level of water in each pond (Table 1).

5. $\triangle \mathrm{GWF}$ was determined from a transformed water balance equation.

As the first step, we calculated the principal parameters of water balance included in Eq. 3. At the second step, we calculated the detailed components of the water balance specified in Eqs. 4 and 5.

\section{Results}

Based on the values of the water balance components calculated using Eq. 3 (Fig. 5), we demonstrated that 
Table 1 Basic information about the studied ponds (Golus, 2014)

\begin{tabular}{lllccc}
\hline No. & Pond area $\left(\mathrm{m}^{2}\right)$ & $\begin{array}{l}\text { Maximum } \\
\text { depth }(\mathrm{m})\end{array}$ & $\begin{array}{l}\text { Total catchment } \\
\text { area }\left(\mathrm{m}^{2} \times 10^{3}\right)\end{array}$ & $\begin{array}{c}\text { Direct catchment } \\
\text { area }\left(\mathrm{m}^{2} \times 10^{3}\right)\end{array}$ & $\begin{array}{l}\text { Water level } \\
\text { amplitude }(\mathrm{cm})\end{array}$ \\
\hline 1 & 361 & 0.81 & 38.5 & 38.5 & 31 \\
2 & 4,152 & 0.82 & 69.5 & 69.5 & 32 \\
3 & 649 & 1.32 & 8.0 & 8.0 & 21 \\
4 & 1,007 & 1.95 & 37.5 & 37.5 & 30 \\
5 & 1,269 & 1.65 & 22.5 & 12.5 & 35 \\
6 & 428 & 1.21 & 66.5 & 15.5 & 63 \\
7 & 311 & 0.96 & 15.5 & 11.5 & 17 \\
8 & 613 & 1.78 & 214.5 & 10.0 & 13 \\
9 & 351 & 0.99 & 866.0 & 55.5 & 39 \\
10 & 203 & 1.82 & 917.5 & 15.5 & 53 \\
11 & 272 & 0.66 & 261.5 & 127.0 & 16 \\
12 & 3,724 & 0.67 & $3,620.0$ & 86.5 & 40 \\
13 & 6,177 & 0.73 & $1,351.0$ & 42.0 & 18 \\
14 & 2,559 & 0.68 & 246.5 & & 19 \\
\hline
\end{tabular}

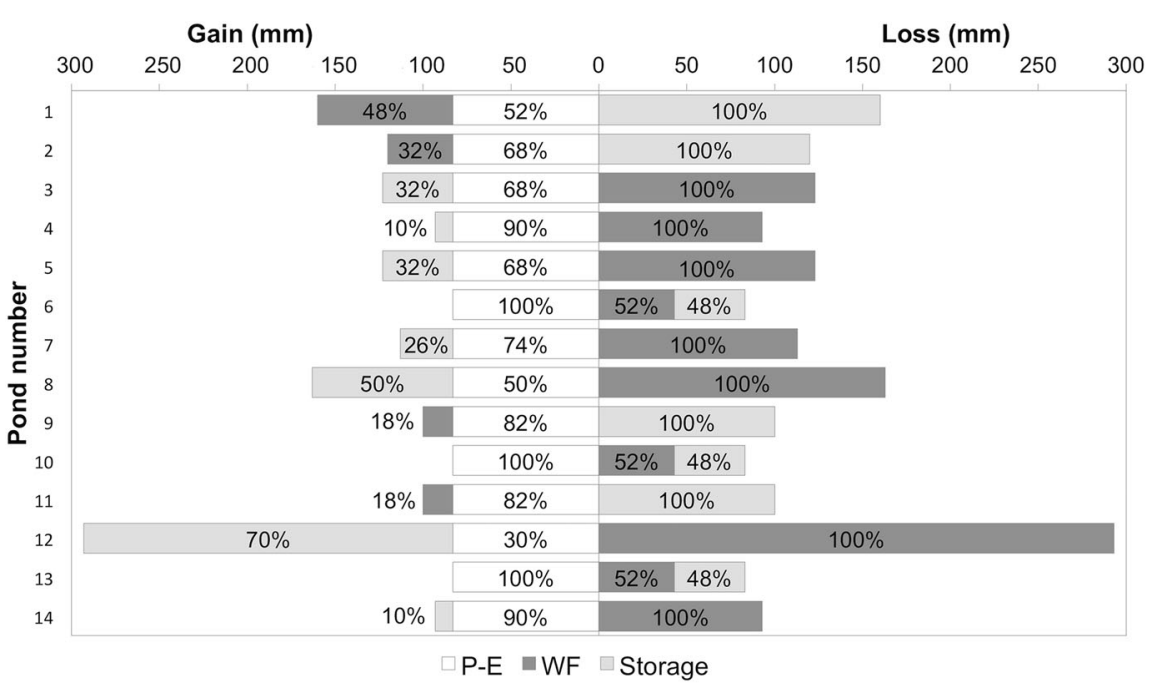

Fig. 5 Water circulation in the moraine ponds of northern Poland in 2009 (values calculated from Eq. 3). Abbreviations $P$ precipitation, $E$ evaporation, $W F$ water flow

only 4 out of the 14 ponds included in the study (Ponds $1,2,9$ and 11) played storage and evaporative functions. These ponds stored $100 \%$ of water gained as a result of (a) atmospheric exchange $(P-E$, where $P>E$ ), with amounts ranging from $52 \%$ of the gain in Pond $1-82 \%$ in Ponds 9 and 11 and (b) net water flow $(\triangle \mathrm{WF})$, with amounts ranging from $18 \%$ of the gain in Ponds 9 and $11-31 \%$ in Pond 2. It is necessary to point out that when $\Delta \mathrm{WF}>0$, WI predominates in a pond and $\Delta \mathrm{WF}$ is a gain (on the left side in Fig. 5). When
$\Delta \mathrm{WF}<0$, WO predominates and $\Delta \mathrm{WF}$ is a loss (on the right side in Fig. 5). When $\Delta S>0$, storage is in fact a loss, because the pond makes up its water deficit with water from $P$ and WI. When $\Delta S<0$, it is a gain, because the pond feeds its water to WO.

In the second type of pond (Ponds 6, 10 and 13), storage and supplying functions predominated. In these ponds, $100 \%$ of the gain was due to $P-E$, while WO and $\Delta S$ were responsible for $52 \%$ and $48 \%$ of the loss, respectively. 
The third type of ponds, supplying ponds, was the most numerous (Ponds 3, 4, 5, 7, 8, 12 and 14). In these ponds, $100 \%$ of WO was made up of $P-E$ and $\Delta S$. Between 28\% (Pond 12) and 89\% (Ponds 4 and 14) of the water gain was due to $P-E$, and between $11 \%$ (Ponds 4 and 14) and 72\% (Pond 12) was due to $\Delta S$.

The total annual amount of water determining water circulation in the ponds ranged from $83 \mathrm{~mm}$ (Ponds 6 , 10 and 13) to $293 \mathrm{~mm}$ (Pond 12) with an average of $124 \mathrm{~mm}$. Assuming that the average area of the pond in our material was $1,719.7 \mathrm{~m}^{2}$, the $124-\mathrm{mm}$ layer corresponded to $213 \mathrm{~m}^{3}$ of water.

During the wet season (early spring), the ponds were connected to the river network, so we used Eqs. 4 and 5 to calculate the water balance components for these water bodies.

The role of $P-E$ lost its significance. We found that only two ponds (Ponds 3 and 14) still maintained their storage and evaporative functions (Fig. 6). In these ponds, the contribution of $P-E$ to the water gain ranged from $60 \%$ (Pond 3) to $89 \%$ (Pond 14). In these ponds, precipitation was responsible for $89 \%$ (Pond 14) to $100 \%$ (Pond 3) of SWO. In the other ponds, $\Delta \mathrm{SWF}$ and $\Delta \mathrm{GWF}$ were the predominant water balance components. These ponds differed from each other in terms of water circulation. In the first group (Ponds 1, 2, 7, 9, 11 and 13), the groundwater influence predominated. These ponds drained aquifers, as indicated by the sign of $\Delta$ GWF. Here, GWI comprised between $91 \%$ (Pond 2) and nearly 100\% (Pond 9) of the water gain. The water surplus originating mainly from GWI activated SWO from these ponds. GWI comprised from $86 \%$ (Pond 2) to $100 \%$ (Pond 7) of the gain, while SWO accounted for $91 \%$ of the loss in Pond 2 and 100\% of the loss in Pond 7. These were, therefore, ponds that drained groundwater reservoirs, redirecting water to the surface, as SWO.

The remaining ponds (Ponds 4, 5, 6, 8, 10 and 12) were supplied by river water, as indicated by the sign of $\triangle \mathrm{SWF}$. The contribution of SWI in water inflow in these ponds was $82 \%$ in Pond 8 and $98 \%$ in Pond 6. The water that supplied to these ponds was "redirected" to groundwater reservoirs in the amounts ranging from $94 \%$ in Pond 10 to $100 \%$ in Ponds 4, 5, 8 and 12. These ponds, therefore, supply SWI into groundwater. When we included $\triangle \mathrm{SWF}$ and $\triangle \mathrm{GWF}$ in the water balance of these ponds, it turned out that the total amount of water involved in water circulation was in fact greater and ranged from $93 \mathrm{~mm}$ in Pond 14 to $27,431 \mathrm{~mm}$ in Pond 9.

As mentioned before, two phases may be distinguished in the functioning of moraine ponds in northern Poland: the dry and the wet phase. The duration of the dry phase ranges from 3 months (Pond 12) to 10 months (Ponds 1, 3, 5 and 6), while the wet phase lasts from 2 months (Ponds 1, 3, 5 and 6) to 9 months (Pond 12) (Fig. 7).

During the dry phase, the monthly $\triangle \mathrm{GWF}$ values were low (ranging from 0 to $134 \mathrm{~mm}$ ), as a result of which the ponds maintained their storage and

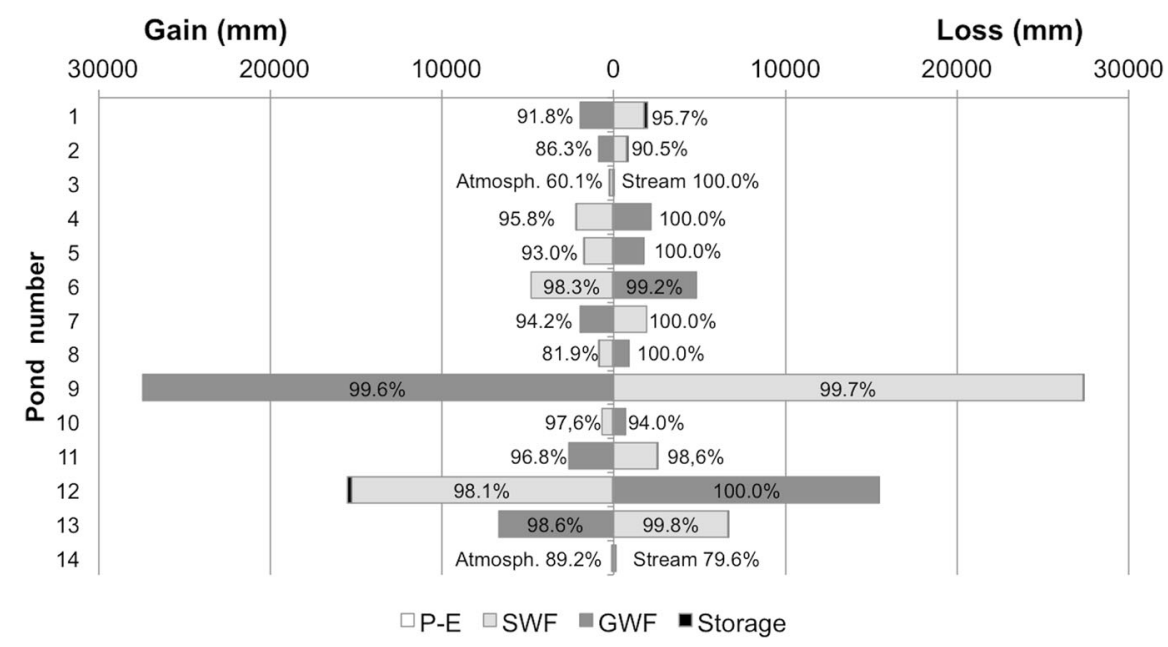

Fig. 6 Water circulation in the moraine ponds of northern Poland in 2009 (values calculated from Eq. 5). Abbreviations $P$ precipitation, $E$ evaporation, $S W F$ streamwater flow, $G W F$ groundwater flow 


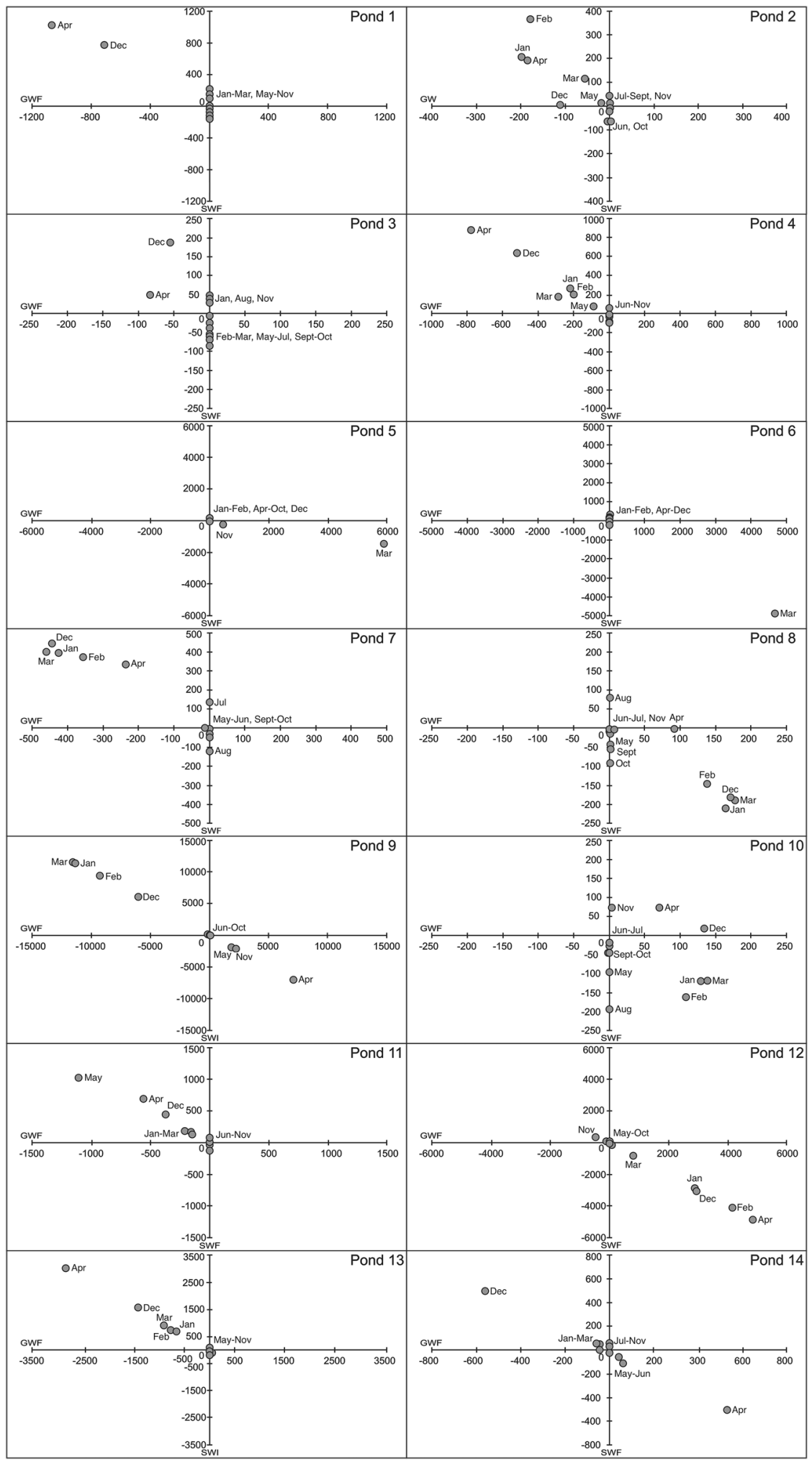

Fig. 7 Stream water flow $(S W F)$ and ground water flow $(G W F)$ in the ponds. Abbreviations Jan January; Feb February etc 
evaporative functions in that period. Groundwater could either supply or drain the pond. The dry phase was observed between late spring and autumn. During the wet phase, the ponds joined the river network. The role of the ponds in their catchment was determined by the type of pond water balance. Ponds 1, 2, 3, 7, 11 and 13 were those which drained groundwater reservoirs and formed SWO, while Ponds 4, 5, 6 and 8 were those which supply SWI to groundwater. There were also ponds (Ponds 9, 10, 12 and 14) whose hydrological function within their respective catchments varied. These pond types drained groundwater and supply streamwater in some months, while supplying groundwater and draining streamwater in others.

\section{Limitations}

Calculation of a pond's water balance (but also that of a lake, a wetland, etc.) involves a number of restrictions. The first issue is, of course, the accuracy of measurement of each element of the water balance. While it is possible to quantitatively determine streamwater inflow, streamwater outflow, precipitation and storage of a pond, evaporation and groundwater flow are very difficult to measure. Evaporation is therefore often calculated from empirical formulas. Evaporation is influenced by many factors, such as water temperature, water mixing, wind velocity, plant overgrowth and water colour. When calculating the water balance we found, however, that the amount of evaporation had a much smaller impact on the water balance of a pond than streamwater and groundwater flow, hence we decided to omit these factors.

Exact measurements of streamwater flow and water level changes are another limitation. While it is possible to determine these two parameters using specialised measuring equipment (automatic flow meters and limnigraphs), it is also very expensive. Due to financial constraints, we had to limit the frequency of measurements to monthly intervals. Additionally, the ponds were private property of farmers, who are very suspicious and reluctant to allow researchers on their land.

Another limitation is the exclusion of subsurface flow from the water balance equations. Subsurface flow depends on many factors, including the shape and size of the direct catchment, surface deposits, land use and many more. Subsurface flow seems to be particularly important during the dry phase. It has a significantly lower impact on ponds connected to the river system. In this case, almost the entire subsurface flow is included in the streamwater inflow $(S W I)$ and groundwater inflow $(G W I)$.

\section{Discussion}

Ponds in Poland are considered almost invisible. The assumption that ponds have no connection with groundwater and streamwater results in that they are considered wastelands. Some researchers do not regard then as a part of the river network and refer to them as small water-filled depressions (Pieńkowski, 2006). In terms of water circulation, ponds are no different from larger water bodies. Our study has shown that ponds situated within the same catchment, not uncommonly in close vicinity to each other, may each have a different hydrological function in water circulation. In contrast to the established view, ponds do not only have storage and evaporative functions modified by groundwater flow (Lehsten et al., 2011), but their water circulation is almost entirely dominated by streamwater flow $(\Delta \mathrm{SWF})$ and groundwater flow $(\Delta \mathrm{GWF})$. These functions may, however, vary from pond to pond. It may be a result of their high hydrogeomorphological diversity (Kalettka \& Rudat, 2006). A given pond may drain groundwater during one period and supply groundwater aquifers in another. The connectivity of ponds with groundwater is of enormous significance for the stability of runoff from the moraine plateaus of northern Poland (Bajkiewicz-Grabowska \& Golus, 2009).

Ponds are even more diverse than larger lakes and rivers (Williams et al., 2004; Biggs et al., 2005; De Meester et al., 2005; Oertli et al., 2005; Davis et al., 2008; Oertli et al., 2009; Céréghino et al., 2012). The interconnection of ponds by streams is also of great importance for the movement of animals and plants. The seasonal intermittent streams that connect the ponds form pathways along which living organisms can migrate. These ponds, during the dry phase, may be used as a "stopover" by these organisms to "take shelter" until the wet season arrives.

The capability of ponds to join the river system during the wet phase has an important bearing on determining the external boundaries of endorheic areas. The ranges of endorheic areas are taken into 
account when calculating the runoff in a given catchment and when assessing the input of the catchment's biogenic elements in a stream or lake (Vollenweider, 1976). Ponds may release stored loads of nutrients from endorheic areas during the wet phase. They may therefore have a great impact on the quality of water in rivers and lakes that are their recipients.

The contact of pond water with groundwater and river water also has great implications for their use. The common belief in Poland is that ponds are devoid of surface outflow and connection with groundwater has so far given us, humans, an unrestricted moral (but also legal) right to do with these bodies of water whatever we pleased. Ponds in Poland are still considered part of wasteland and pond owners believe that anything you do with the ponds will be better than just leaving these water bodies alone. They therefore drain the ponds and fill them in, convert them into fish ponds, use them for disposing of sewage and waste. And it is important that we change this way of thinking sooner better than later.

\section{Conclusion}

Ponds are small objects and despite their omnipresence, it is easy to overlook them when calculating water circulation of larger lakes, rivers, or basins. Our relatively simple method using the water balance equation shows that ponds are not only connected with groundwater but also shape and "control" runoff from the catchment. They are dynamic objects that affect whole water cycle in the region. Our results indicate that ponds play more important role in the environment of moraine plateaus than was previously thought.

The hydrological functions of ponds situated on the moraine plateaus of northern Poland vary from pond to pond, but it is dependent almost entirely on streamwater flow and groundwater flow. The ponds we studied displayed a wet-dry cycle. During the dry cycle, when the ponds became water bodies without surface outflow, they exist because they are a drainage base for the shallow groundwater. As the amount of water in the cycle increases (the spring melt), the ponds become connected with the river network and initiate stream water outflow. Streamwater outflow results in water surplus within the catchment, as ponds are a storage base for catchment water. As the result of their connectivity with groundwater, ponds rarely dry up.
The wet phase of the ponds lasts from 3 to 10 months, depending on the topographic location of each pond. The main hydrological function of the moraine plateau ponds in the dry phase is to retain water surplus originating from atmospheric exchange $(P-E)$ and to retain water from underground drainage and surface inflow. During the wet phase, ponds activate stream- and groundwater outflow $(\mathrm{SWO}+\mathrm{GWO})$. Even neighbouring ponds may have opposite hydrological functions within a catchment. Some of them may drain groundwater and shape streamwater outflow, while the neighbouring ponds may "convert" streamwater into groundwater outflow. The ponds located on the moraine plateaus of northern Poland, therefore, deserve a greater interest on the part of researchers, regulation of their legal status and provision of legal protection.

Open Access This article is distributed under the terms of the Creative Commons Attribution 4.0 International License (http:// creativecommons.org/licenses/by/4.0/), which permits unrestricted use, distribution, and reproduction in any medium, provided you give appropriate credit to the original author(s) and the source, provide a link to the Creative Commons license, and indicate if changes were made.

\section{References}

Biggs, J., P. Williams, M. Whitfield, P. Nicolet \& A. Weatherby, 2005. 15 years of pond assessment in Britain: results and lessons learned from the work of pond conservation. Aquatic Conservation: Marine and Freshwater Ecosystems 15: 693-714.

Boix, D., J. Biggs, R. Céréghino, A. Hull, T. Kalettka \& B. Oertli, 2012. Pond research and management in Europe: small is beautiful. Hydrobiologia 689: 1-9.

Bajkiewicz-Grabowska E., \& W. Golus, 2009. Organizacja sieci hydrograficznej w zlewni pojeziernej przy różnym stanie jej retencji. [w:] Bogdanowicz, R. \& J. Fac-Beneda (red.), Zasoby i ochrona wód. Obieg wody i materii w zlewniach rzecznych. Fundacja Rozwoju Uniwersytetu Gdańskiego, Gdańsk: 159-166.

Céréghino, R., B. Oertli, M. Bazzanti, C. Cozzia, A. Compin, J. Biggs, M. Bressi, P. Grillas, A. Hull, T. Kalettka \& O. Scher, 2012. Biological traits of European pond macroinvertebrates. Hydrobiologia 689: 51-61.

Choiński A., 1999. Oczka wodne w Polsce w strefie zasięgu zlodowacenia bałtyckiego. Acta Universitatis Nicolai Copernici, Geografia XXIX, 103, UMK, Toruń: 317-326.

Davie, T., 2008. Fundamentals of Hydrology. Routledge Fundamentals of Physical Geography, 2nd ed. Routledge/ Taylor \& Francis Group, London/New York.

Davis, R. R., J. Biggs, P. J. Williams, J. T. Lee \& S. Thompson, 2008. A comparison of the catchment sizes of rivers, 
streams, ponds, ditches and lakes: implications for protecting aquatic biodiversity in an agricultural landscape. Hydrobiologia 597: 7-17.

De Meester, L., S. Declerck, R. Stocks, G. Louette, F. Van de Meutter, T. De Bie, E. Michels \& L. Brendonck, 2005. Ponds and pools as model systems in conservation biology, ecology and evolutionary biology. Aquatic Conservation: Marine and Freshwater Ecosystems 15: 715-725.

Downing, J. A., 2010. Emerging global role of small lakes and ponds: little things mean a lot. Limnetica 29: 9-24.

Drwal J.,1982. Wykształcenie i organizacja sieci hydrograficznej jako podstawa oceny struktury odpływu na terenach młodoglacjalnych. Zeszyty Naukowe Uniwersytetu Gdańskiego, Rozprawy i monografie, z. 33, Gdańsk.

Drwal J., 1990. Quasiedoreizm w Europie Środkowej. Przegląd Geograficzny, t. LXII, z.: 3-4.

Drwal, J. \& W. Lange, 1985. Niektóre limnologiczne odrębności oczek. Geneza i rozmieszczenie oczek. Zeszyty Naukowe WBiNoZ Uniwersytetu Gdańskiego. Geografia 14: 69-83.

Ferone, J. M. \& K. J. Devito, 2004. Shallow groundwater-surface water interactions in pond-peatland complexes along a Boreal Plains topographic gradient. Journal of Hydrology 292: 75-95.

Fiedler, M., 2002. Bilanse wodne mikrozlewni rolniczych z występującymi śródpolnymi oczkami wodnymi. Wiadomości Melioracyjne i Łąkarskie 45(2): 69-73.

Gerke, H. H., S. Koszinski, T. Kalettka \& M. Sommer, 2010. Structures and hydrologic function of soil landscapes with kettle holes using an integrated hydropedological approach. Journal of Hydrology 393(1-2): 123-132.

Golus W., 2014. Obieg materii w małych zbiornikach pojeziernych, $\mathrm{PhD}$ thesis.

Kalettka, T. \& C. Rudat, 2006. Hydrogeomorphic types of glacially created kettle holes in North-East Germany. Limnologica 39(1): 54-64.

Kalettka, T., C. Rudat \& J. Quast, 2001. "Potholes" in Northeast German agro-landscapes: functions, land use impacts, and protection strategies. In Tenhunen, J. D., R. Lenz \& R. Hantschel (eds), Ecosystem Approaches to Landscape Management in Central Europe. Ecological Studies, Vol. 147. Springer, Berlin: 291-298.

Lischeid, G. \& T. Kalettka, 2012. Grasping the heterogeneity of kettle hole water quality in Northeast Germany. Hydrobiologia 689: 63-77.

Lehsten, D., J. Von Asmuth \& M. Kleyer, 2011. Simulation of water level fluctuations in kettle holes using a time series model. Wetlands 31: 511-520.

Major, M., 2009. Charakter i funkcjonowanie zagłębień bezodpływowych w krajobrazie strefy młodoglacjalnej (Pomorze Zachodnie, górna Parsęta). Wydawnictwo Poznańskiego Towarzystwa Przyjaciół Nauk, Poznań.

Marszelewski, W. \& P. Podgórski, 2004. Zmiany ilościowe oczek i jezior na Pojezierzu Chełmińskim w świetle materiałów kartograficznych z XIX i XX wieku. Przegląd Geograficzny 76: 33-50.
Noges, P., T. Noges, L. Tuvikene, H. Smal, S. Ligeza, R. Kornijow, W. Peczula, E. Becares, F. Garcia-Criado, C. Alvarez-Carrera, C. Fernandez-Alaez, C. Ferriol, R. M. Miracle, E. Vicente, S. Romo, E. Van Donk, W. Van De Bund, J. P. Jensen, E. M. Gross, L.-A. Hansson, M. Gyllstrom, M. Nykänen, E. de Eyto, K. Irvine, D. Stephen, S. Collings \& B. Moss, 2003. Factors controlling hydrochemical and trophic state variables in 86 shallow lakes in Europe. Hydrobiologia 506: 51-58.

Oertli, B., J. Biggs, R. Céreghino, P. Grillas, P. Joly \& J.-B. Lachavanne, 2005. Conservation and monitoring of pond biodiversity: introduction. Aquatic Conservation: Marine and Freshwater Ecosystems 15: 535-540.

Oertli, B., R. Céreghino, A. Hull \& R. Miracle, 2009. Pond conservation: from science to practice. Hydrobiologia 634 : $1-9$.

Pieńkowski, P., 2004. Disappearance of ponds in landscape of Northern Europe as an effect of anthropogenic influence and global climate change. Polish Journal of Environmental Studies 13: 192-196.

Pieńkowski, P., 2006. Distribution of small, water-filled depressions as a component of the analysis of icesheet retreat dynamics in young glacial areas. Landform Analysis 6: 41-46.

Skalbeck, J. D., D. M. Reed, R. J. Hunt \& J. D. Lambert, 2009. Relating groundwater to seasonal wetlands in southeastern Wisconsin, USA. Hydrogeological Journal 17: 215-228.

Vollenweider, R. A., 1976. Advances in defining critical loading levels for phosphorus in lake eutrophication. Memorie Dell'Istituto Italiano Di Idrobiologia 33: 53-83.

Waldon, B., 2012. Natural value and endangerment of small water reservoirs in the Krajeńskie Lakeland (North-West Poland). Limnologica 42: 320-327.

Wetzel, R. W., 2001. Limnology: Lake and River Ecosystems. Academic Press, San Diego, CA.

Williams, P., J. Biggs, A. Whitfield, S. Throne, G. Bryant, G. Fox \& P. Nicolet, 1999. The Pond Book: A Guide to the Management and Creation of Ponds. Ponds Conservation Trust, Oxford.

Williams, P., M. Whitfield, J. Biggs, S. Bray, G. Fox, P. Nicolet \& D. Sear, 2004. Comparative biodiversity of rivers, streams, ditches and ponds in an agricultural landscape in Southern England. Biological Conservation 115: 329-341.

Winter, T. C. \& D. O. Rosenberry, 1995. The interaction of ground-water with prairie potholes wetlands in the cottonwood lake area, East-Central North Dakota, 1979-1990. Wetlands 15: 193-211.

Woo, M. K. \& R. D. Rowsell, 1993. Hydrology of a prairie slough. Journal of Hydrology 146: 175-207. 